\author{
Grzegorz Peiczyński \\ (D) https://orcid.org/0000-0003-4620-1003 \\ Katedra Etnologil i Antropologit Kulturowej \\ UNIWERSYTET WROCEAWSKI
}

\title{
GRISZA ASZWAJANC I INNI ORMIANIE W TRYLOGII UKRAIŃSKIEJ JÓZEFA ŁOBODOWSKIEGO
}

\begin{abstract}
Abstrakt: Artykuł zawiera analizę obrazu Ormian i ich losów w cyklu powieściowym polskiego pisarza emigracyjnego - Józefa Łobodowskiego (1909-1988). Cykl ten, zwany trylogią ukraińską (Komysze, 1955; W stanicy, 1958; Droga powrotna, 1960), oparty jest na przeżyciach własnych autora, który młodość spędził na Kubaniu podczas pierwszej wojny światowej i tuż po rewolucji bolszewickiej. Ormianie nie stanowią $\mathrm{w}$ tej trylogii jedynie orientalnego ozdobnika. Łobodowski, pisząc o nich, realizował poważniejszy zamysł. Zdaje się sugerować, że przyjaźń między bohaterem powieści, Stasiem Majewskim, a ormiańskim chłopcem Griszą Aszwajancem to nie tylko nieprawdopodobne przygody, ale przede wszystkim skuteczny sojusz słabych wobec zagrażających im potęg. Sojusz wcale nie tylko indywidualny, ale taki, który łączyć może wręcz całe narody.
\end{abstract}

Słowa kluczowe: Józef Łobodowski, Kubań, Ormianie, literatura polska

W dziełach zaliczanych do literatury polskiej czyta się przede wszystkim o Polakach. Oczywiście nic w tym nadzwyczajnego, po to ona bowiem istnieje, aby zajmować się ich sprawami. Jednakże w sprawach Polaków nader często uczestniczyli przedstawiciele innych nacji, toteż spotkać ich można wśród bohaterów wymyślonych przez polskich pisarzy. Kreując bohaterów, posługują się oni wiedzą nabytą $\mathrm{w}$ toku obcowania $\mathrm{z}$ nie-Polakami. Wiedza ta pochodzić może również z badań archiwalnych czy odpowiednio dobranej lektury. A niekiedy wiadomości pisarzy o innych narodach to ni mniej, ni więcej tylko stereotyp. Historyk zapewne najbardziej doceni utwory, w których bohaterowie wzorowani są na 
ludziach żyjących w konkretnym czasie i miejscu. Do zadań pisarzy nie należy jednak tworzenie źródeł historycznych, a zatem nieważne jest, skąd pochodzi użyta przez nich materia.

W powieściach, opowiadaniach i nowelach polskich autorów pojawiają się niekiedy Ormianie. Dodać koniecznie trzeba, że zdarza się to bardzo rzadko. Wprawdzie w ciągu dziejów Polacy mieli okazje stykać się z Ormianami, zwłaszcza z kupcami i rzemieślnikami w miastach i miasteczkach dawnej Polski, ale raczej nie byli z nimi skonfliktowani, więc, można rzec - nie było o czym się rozpisywać. Zdarzali się jednak tacy pisarze, którzy stworzyli w swych utworach ciekawe postacie Ormian. Niewątpliwie niejedna z nich godna jest zapamiętania. Czynią polską literaturę bardziej interesującą, bogatszą o kilka frapujących tematów.

Bodaj po raz pierwszy na Ormian w literaturze polskiej zwrócił uwagę Zbigniew Kościów ${ }^{1}$. W swym prekursorskim szkicu wymienił i pokrótce omówił różne utwory, w których znaleźć można właśnie „motyw ormiański”. Warto tu przytoczyć jego konkluzje:

Już z przedstawionych danych wywnioskować można, że motyw ormiański odcisnął się dość wyraźnie na twórczości sporej liczby polskich pisarzy. Wykorzystanie tego motywu sięga od orientalnego ozdobnika o epizodycznej funkcji do szeroko rozwiniętego elementu o ważnym znaczeniu. Większość naszych autorów przypisała Ormianom dodatnie cechy i zajęła życzliwe stanowisko $\mathrm{w}$ ormiańskich sprawach. Zainteresowanie wątkami ormiańskimi przejawiali głównie autorzy powieści historycznych, których akcja toczy się albo na wschodnich terenach dawnej Polski, albo w krajach orientalnych. Ze zrozumiałych względów polscy pisarze podkreślali głównie polsko-ormiańskie związki, ale nieraz zaznaczali kontakty Ormian także z innymi narodami żyjącymi niegdyś w Rzeczypospolitej. Rzadziej występuje ów motyw w polskich powieściach o tematyce współczesnej lub bliskiej współczesności i właśnie w niektórych z nich zauważyć można tendencję do „odbrązawiania” Ormian. Pozytywy jednak przeważają, są przysłowiową regułą potwierdzoną przez wyjątki. Nie wynika to $\mathrm{z}$ kurtuazyjnej idealizacji Ormian, ale z realiów znanych autorom $\mathrm{z}$ autopsji czy pisanych dokumentów ${ }^{2}$.

Kościów nie wspomina jednakże dzieł Józefa Łobodowskiego. Bynajmniej nie przynosi to ujmy temu wybitnemu znawcy problematyki ormiańskiej. W artykule z końca lat osiemdziesiątych XX wieku cenzor może by już nie skreślił nazwiska emigracyjnego literata, lecz jego twórczość, szczególnie prozatorska, była w kraju zupełnie nieznana. Powieści składające się na tak zwaną trylogię

\footnotetext{
1 Z. Kościów, Motyw ormiański w literaturze polskiej, „Opole”, 8, 1987, s. 22, 28.

2 Ibidem, s. 28.
} 
ukraińską, w której występują liczni Ormianie, w kraju wydano po raz pierwszy dopiero w 2017 roku$^{3}$.

Trudno przejść obojętnie obok Ormian w trylogii Łobodowskiego. Jeden z nich - Grisza Aszwajanc - należy do jej głównych bohaterów. Już sam ten fakt jest niezwykły, bo przecież na ogół Ormianie w polskiej literaturze to postacie często wyraźne, ale epizodyczne. Aczkolwiek takich również w tej trylogii nie brakuje. Zanim te wyjątkowe postacie zostaną tu przywołane i szczegółowo scharakteryzowane, napisać trzeba o ich twórcy ${ }^{4}$. Jest to nieodzowne, by w pełni pojąć jego dokonania beletrystyczne, gdyż w opowiadane przez siebie historie wplatał liczne wątki autobiograficzne.

Łobodowski urodził się w Purwiszkach na Suwalszczyźnie w 1909 roku w rodzinie ziemiańskiej. Wkrótce po jego urodzeniu państwo Łobodowscy sprzedali majątek, po czym przenieśli się do Lublina. Gdy wybuchła pierwsza wojna światowa, ojciec przyszłego pisarza, Władysław Łobodowski, będący pułkownikiem armii carskiej, wyjechał do Rosji, zabierając ze sobą rodzinę. Do wybuchu rewolucji październikowej, Łobodowscy przebywali głównie w Moskwie. Lata 19171922 dla nieletniego Józefa były wyjątkowo trudne. Mieszkał wtedy z rodzicami i dwiema siostrami na Kubaniu, w Jejsku, niewielkim mieście portowym nad Morzem Azowskim ${ }^{5}$. Rozpoczął naukę w gimnazjum rosyjskim, ale rychło musiał ją przerwać. Wojna domowa całkowicie uniemożliwiła żywot typowy dla młodzieńca ze środowiska inteligenckiego. Ojciec, pozbawiony pracy, nękany przez ciągle zmieniające się władze, nie mógł zapewnić utrzymania rodzinie. To zadanie spadło na Józefa, który wyspecjalizował się w handlu papierosami. W tym trudnym okresie krzepiła nadzieja na powrót do Polski. Ale nie było pewne, czy uda się do niego dożyć. Jego ojcu się nie udało, umarł kilka tygodni przed wyjazdem. Wcześniej umarła jedna z sióstr. W połowie 1922 roku Józef Łobodowski wyjeżdżał więc do ojczyzny tylko z matką i starszą z sióstr.

Następne lata spędził przeważnie w Lublinie. Tam uzyskał świadectwo dojrzałości i zaczął studiować prawo w Katolickim Uniwersytecie Lubelskim, kierunku jednak nie ukończył. W tym mieście zaczął też działalność literacką jako poeta. W pierwszej połowie lat trzydziestych Łobodowski wyznawał poglądy lewicowe, wręcz komunistyczne, i przestawał z ludźmi o podobnych zapatrywaniach. Przysparzało mu to rozlicznych problemów, z wyrokami pozbawienia wolności włącznie. Lecz w połowie tej dekady zrozumiał, że idzie złą drogą i całkowicie się nawrócił, a nawet stał się nieprzejednanym antykomunistą. W roku 1938 ożenił się z Jadwigą z Kuryłłów. Młodzi małżonkowie przez kilka miesięcy

3 Lublin, nakładem Wydawnictwa Test. 2001.

${ }^{4}$ I. Szypowska, Łobodowski. „Od atamana Łobody” do ,, seniora Lobo”, Warszawa

${ }^{5} \mathrm{~W}$ tym regionie w tym czasie znajdowały się małe skupiska Polaków: А. Селицкий, Поляки на Кубани: исторические очерки, Краснодар 2008, s. 103-130. 
mieszkali w Łucku, a następnie przenieśli się do Warszawy. Łobodowski walczył w kampanii wrześniowej 1939 roku i ze swoim oddziałem został internowany na Węgrzech. Stamtąd udało mu się uciec do Francji, gdzie zamierzał kontynuować walkę. Niestety został aresztowany i osadzony w obozie dla zdemobilizowanych żołnierzy polskich. Wyszedł zeń dopiero po zajęciu Francji przez Niemcy. Podjął wówczas próbę przedostania się przez Hiszpanię i Portugalię do Anglii, do stacjonujących tam polskich oddziałów wojskowych. Zaaresztowany przez policję hiszpańską, przesiedział dwa lata w obozie w Figueras. Resztę życia spędził w Madrycie. Od 1949 roku prowadził audycje polskie nadawane przez Radio Madryt. Były to pierwsze programy radiowe emitowane z Zachodu do kraju. $\mathrm{Z}$ powodu tej działalności jego żonę, przebywającą w Polsce, władze komunistyczne zmusily do rozwodu. Oprócz pracy w radiu zajmował się twórczością literacką, a swoje utwory publikował w wydawnictwach i czasopismach emigracyjnych. Umarł w 1988 roku. Jego prochy pochowano w rodzinnym grobie w Lublinie.

Jak dotychczas Łobodowski ceniony jest jako poeta. Jego dorobek poetycki opublikowany w kraju doczekał się niejednego omówienia ${ }^{6}$. Autor nie był natomiast znany jako prozaik, a w każdym razie w niewielkim stopniu?. Jego proza w dużej mierze ma charakter autobiograficzny. Żywot człowieka gwaltownego, wydany w kraju w 2014 roku, to wspomnienia. Ale też mnóstwo swoich reminiscencji, artystycznie przetworzonych, zawarł w dwóch cyklach powieściowych. Najpierw może o drugim w kolejności, o Dziejach Józefa Zakrzewskiego. Składające się nań cztery tomy opublikowano w latach 1965-1970, w Polsce zaś, dzięki Wydawnictwu Test, w 2018 roku. Autor wykorzystał w nim swoje doświadczenia z lat trzydziestych.

Wcześniejszy cykl, nazywany trylogią ukraińską, to trzy powieści, nad którymi Łobodowski pracował w pierwszej połowie lat pięćdziesiątych, kiedy leczył się z gruźlicy ${ }^{8}$, a następnie wydawał w londyńskim wydawnictwie Gryf: Komysze w 1955 roku, W stanicy w 1958 roku, Droga powrotna w 1960 roku. Wydawnictwo Test wydało je w Lublinie w roku 2017, a ponownie wyszły nakładem Instytutu Literatury w Krakowie w 2020 roku. W trylogii ukraińskiej Łobodowski sięgnął do tego, co przeżył w latach po rewolucji październikowej, które spędził w Jejsku. Właśnie w powieściach składających się na ten chronologicznie wcześniejszy cykl znaleźć można interesujące postacie Ormian.

${ }^{6}$ Zob. np. A. Jakubowska-Ożóg, Poezja emigracyjna Józefa Łobodowskiego, Rzeszów 2001; L. Siryk, Naznaczony Ukraina. O twórczości Józefa Łobodowskiego, Lublin 2002.

7 P. Libera, Na marginesie „Dziejów Józefa Zakrzewskiego” (uwagi historyka), w: J. Łobodowski, Dzieje Józefa Zakrzewskiego. Część pierwsza, Rzeka graniczna, b.m.w. 2018, s. 243.

${ }^{8}$ I. Szypowska, Lobodowski, s. 145. 
Bohaterem tych trzech powieści jest Staś Majewski. Jak ongiś sam Łobodowski, mieszka on w Jejsku wraz z rodzicami i dwiema siostrami. Jego ojciec jest pułkownikiem carskiej armii, teraz jednak niewykonującym swego zawodu. Rodzina utrzymuje się z wyrabiania papierosów, które Staś sprzedaje na ulicach. Choć niespełna dwunastoletni, ma już dziewczynę - Szurę. Gdy jeszcze do niedawna uczęszczał do gimnazjum, kochał się w Ninie, w obronie której bił się z napastującym ją kolegą. Z powodu toczącej się wojny domowej życie nawet w prowincjonalnym Jejsku jest coraz bardziej niebezpieczne. Młody Majewski wraz z Szurą przenosi się w komysze, trudno dostępne tereny rozciągające się poza miastem nad samym morzem. Zamierza do tego miejsca sprowadzić także rodzinę, ale okazuje się, że w komyszach wcale nie jest bezpiecznie. Podczas strzelaniny między rywalizującymi ze sobą bandami dosięga go przypadkowa kula. Dzięki pomocy przyjaciół zostaje przewieziony do kozackiej stanicy. Tam zdrowieje. Potem przez kilka miesięcy żyje pośród Kozaków, w pełni przez nich akceptowany. Ma nową dziewczynę - Katię. Pewnego razu na stanicę napada silny oddział bolszewików. Mimo dzielnej obrony wróg wkracza do wioski i masakruje jej ludność. Śmierci nie unika również ukochana Stasia. Przeżywszy atak na stanicę, a potem jeszcze liczne przygody, Staś wraca do Jejska. W domu Majewskich akurat zmarł ojciec. Chłopiec znów romansuje z Szurą. Pojawia się możliwość powrotu do Polski. Majewscy przygotowują się do podróży. Staś namawia Szurę, aby jechała z nim, ale ona odmawia. W dzień wyjazdu przychodzi do niej, by się pożegnać. Potem idzie do portu, skąd miał odpłynąć statek $\mathrm{z}$ repatriantami. Dowiaduje się, że statek odpłynął godzinę wcześniej, niż powinien. Zostawszy w mieście sam, nie wie, co robić. W końcu milicja zamyka go w sierocińcu, w którym wychowawcy bestialsko znęcają się nad podopiecznymi. Przebywa w nim także Nina, w której kochał się w czasach gimnazjalnych. Pewnego razu zgwałcona przez wychowawców, popełnia samobójstwo. Następnie w sierocińcu wybucha bunt, dzięki czemu młodzi więźniowie mogą uciec. Staś ukrywa się na terenie Jejska. Potem wraz z Szurą idzie do Rostowa nad Donem. Tam oboje znajdują schronienie wśród Ormian, czekając na okazję wyjazdu do Polski. Niespodziewanie Szura zapada na tyfus i umiera. Staś w towarzystwie innej dziewczyny wyrusza pieszo do kraju.

Trylogia Łobodowskiego jest pełna przygód. Pod tym względem przywodzi na myśl powieści Henryka Sienkiewicza, jego trylogię, a nawet $W$ pustyni $i$ w puszczy, a ponadto utwory Aleksego Tołstoja i Aleksego Szołochowa9. Zapewne nie wszystkie przygody opisane w trylogii Łobodowskiego - tylko część z nich znalazła się w powyższym streszczeniu - przeżył osobiście autor lub któryś z jego znajomych. W każdym razie żył w tym samym miejscu i czasie, co Staś Majewski, a zatem trudno zupełnie podważyć jego wiarygodność. Na pewno nie

\footnotetext{
9 A. Danilewicz-Zielińska, Szkice o literaturze emigracyjnej, Wrocław 1999, s. 264.
} 
puszcza wodzy fantazji, opisując okrucieństwa bolszewików i chaos, jaki zapanował w społeczeństwie rosyjskim po rewolucji. Wiarygodny jest także w jego opisach Kubań, obszar północno-zachodniego Kaukazu, przylegający do Morza Azowskiego. Kubań wielonarodowy, z licznymi stanicami Kozaków, mówiących po ukraińsku ${ }^{10}$. Może właśnie dlatego te trzy powieści określa się mianem trylogii ukraińskiej.

Kubań to kraina, w której od dawien dawna osiedlali się także Ormianie. Wizerunki przedstawicieli tego narodu znaleźć można więc w wielu miejscach dzieła Łobodowskiego. W pierwszej kolejności wymienić tu trzeba postać Griszy Aszwajanca. Jest to przyjaciel głównego bohatera cyklu. Młody Polak wychodził cało z największych opresji tylko dzięki niemu. Bo też obaj byli kunakami, a więc wyjątkowymi przyjaciółmi, których więź utrwalił specjalny obrzęd, polegający na nacinaniu żył i piciu krwi tego, z kim się zawierało kunactwo. W najnowszym wydaniu powieści odredakcyjny przypis informuje, że taki układ na Kaukazie Północnym zwykli ustanawiać między sobą mężczyźni należący do dwóch różnych ludów ${ }^{11}$. Już sam wygląd Aszwajanca był niezwykły. Autor tak go opisuje, wprowadzając po raz pierwszy do swojej powieści:

Mimo lata miał na sobie barani kożuszek bez rękawów, na nogach szmaty z worków, przymocowane rzemieniami, szeroki pas i na czarnym zmierzwionym łbie kubańską czapkę z czerwonym denkiem [...]. Miał gębę spaloną na ciemny brąz, olbrzymie oczy i nos w kształcie zakrzywionego ogórka. Długie małpie ramiona, zakończone potężnymi dłońmi, uzupełniały całość. Kaukaski zbój, półdziki czaban ze stepów stawropolskich, zbieg z katorgi - każde określenie pasowało do Griszy Aszwajanca ${ }^{12}$.

A oto inna jego charakterystyka, którą autor wkłada w usta jednego z poślednich bohaterów powieści:

Jeden bandzior się o ciebie dopytywał. Nie z naszych, Ormiaszka, znaczy się... Karapiet... Nos jak ogórek, ślepia jak u wilka. Griszka na niego wołają ${ }^{13}$.

Użyto tu określenia „Karapiet”, będącego popularnym imieniem ormiańskim, którym w Rosji nazywa się, raczej niepochlebnie, wszystkich Ormian. Aszwajanc jednak nazywany jest najczęściej Griszką, co jest rosyjskim zdrobnieniem imienia Grigorij. Wynika to pewnie stąd, iż żyje wśród Rosjan bądź ludności ro-

10 Zob. I. Szypowska, Łobodowski, s. 192.

11 J. Łobodowski, Komysze, Kraków 2020, s. 53; por. T. Kaliściak, Pobratymstwo $w$ świetle źródeł historyczno-etnograficznych z przełomu XVIII i XIX wieku, „Konteksty”, 2020, 4, s. 209-217.

12 J. Łobodowski, Komysze, [Lublin] 2017, s. 16.

13 Idem, Droga powrotna, [Lublin] 2017, s. 102-103. 
syjskojęzycznej. Po ormiańsku jego imię brzmi Krikor, czyli Grzegorz. To również popularne imię ormiańskie. Łobodowski jednak go tak nigdy nie nazywa.

Ze Stasiem Majewskim poznał się Aszwajanc w gimnazjum. Chyba chodzili do jednej klasy, choć Ormianin był o trzy lata starszy od Polaka, gdyż nieraz repetował. Może przyciągnął ich do siebie status mniejszościowy, obaj nie byli wszak Rosjanami i Rosjanie okazywali im czasami nieufność, a nawet wzgardę, można się domyślić, że także w szkole. Jednakże akcja powieści nie dzieje się w okresie gimnazjalnym, lecz w czasach, kiedy to byli gimnazjaliści musieli sami troszczyć się o siebie, a nierzadko też o swoich bliskich. Ormianin radzi sobie znakomicie. Staje się ważną postacią w środowiskach przestępczych. Jednak nie pasuje do niego miano bandyty. To człowiek bardzo szlachetny, wprawdzie zdolny do okrucieństwa, ale tylko wobec tych, którzy zdają się na nie zasługiwać, którzy krzywdzą słabych i bezbronnych. Z reguły to osobnicy wykreowani przez rewolucję. Ma świadomość bycia kimś niezwykłym. Na stronach Drogi powrotnej mówi o sobie: „Ja jestem kaukaski orzeł, przede mną najtęższe milicjanty uciekają"14. A w innym miejscu: „Griszka Aszwajanc, Ormiaszka, kaukaski bandyta i mściciel za ludzkie krzywdy”15. I jeszcze: „Nikogo nie uznaję, żyję jak chcę, własną głową, własnym przemysłem" ${ }^{16}$. Jako taki w dużej mierze przypomina bohaterów romantycznych ${ }^{17}$.

Przypomina ich także swą orientalną proweniencją - wywodzi się ze starożytnego wschodniego ludu. Ponadto zna inne ludy wschodnie żyjące na Kaukazie i jego wiedza na ich temat pozytywnie wyróżnia go wśród znajomych Rosjan, których one w jakiejś mierze fascynują. Jeden z bohaterów, Rosjanin, Kola, żegnając się z towarzystwem, zwraca się do Aszwajanca:

- Ty, Griszka, specjalista od tych waszych kaukaskich ceremonii. Jak to się mówi, gdy ktoś kunaka żegna? Salem-alejkum.

Ormianin uśmiechnął się z zadowoleniem i przyłożył dłoń do serca, ust i czoła.

- Aławendy... Mahomet Rassul Ałła... Faticha!

- Wałłabałła! Inszach!

- Ałła sechła!18

Jest on niewątpliwie ormiańskim patriotą, choć żyje z dala od ojczyzny. W rozmowie z Awdotienką, rozczarowanym rewolucjonistą, któremu pomaga się ukrywać, powiada:

\footnotetext{
14 Ibidem, s. 76.

15 Ibidem, s. 122.

16 Ibidem, s. 127.

17 Zob. M. Urse1, Romantyzm, Wrocław 2000, s. 165-166.

18 J. Łobodowski, Komysze, [Lublin] 2017, s. 79.
} 
Piękne są góry, a już najpiękniejsze u nas w Armenii. Wszędzie strumienie lecą, zieloności w bród, winnice na zboczach, stada baranków chodzą. Pastuch koło nich, na duduku przygrywa ${ }^{19}$.

Od czasu do czasu ma dość życia w konspiracji i wówczas snuje plany powrotu do ojczyzny, może nawet z grecką kochanką:

Zabrać by Łarisę do Armenii, osiedlić się w górach, nie musieć kryć się przed milicją i coraz to zmieniać meliny ${ }^{20}$.

Innym razem Armenia to miejsce, gdzie będzie się można schronić, gdy dotychczasowy tryb życia stanie się niemożliwy:

Za ciasno się zrobi, pójdę w góry, w nasze ormiańskie strony, nad turecką albo perską granicę ${ }^{21}$.

Staś namawia go, by wyjechał z nim do Polski, gdzie też żyją Ormianie, ale słyszy w odpowiedzi:

Ja jeżeli stąd wyjdę - powiada - to do mojego kraju, w nasze ormiańskie góry ${ }^{22}$.

Czytelnik nie dowiaduje się, jak potoczyły się losy Aszwajanca. Łobodowski pozwala jeszcze, aby po raz ostatni zadbał o swego polskiego kunaka i wyprawił go w drogę do Polski.

W omawianych powieściach pojawiają się też inni Ormianie, lecz żaden nie dorównuje Aszwajancowi, choć wszystkie postaci ormiańskie są pozytywne. Aczkolwiek ojciec Stasia nie miał o nich i o innych narodach parających się handlem zbyt dobrej opinii:

Łapownicy, oszuści! Jeśli nie Ormianin Greka, to Grek Ormianina przehandluje za kilka groszy ${ }^{23}$.

I w związku z tym

opowiadał anegdotę o burzy na morzu, która natychmiast uspokoiła się, gdy z okrętu do wzburzonych fal wyrzucono Żyda, Greka i Ormianina. Po pewnym czasie złowiono wieloryba, po rozcięciu którego okazało się, że w brzuchu siedzą wszyscy trzej i grają w karty. Żyd przegrał wszystko, nawet ubranie i bieliznę, nawet osobistą wolność i właśnie w chwili złowienia wieloryba Grek i Ormianin grali o Żydka w durnia ${ }^{24}$.

19 Idem, Droga powrotna, s. 127.

${ }^{20}$ Ibidem, s. 132.

${ }^{21}$ Ibidem, s. 235.

${ }^{22}$ Ibidem, s. 419.

${ }^{23}$ J. Łobodowski, Komysze, [Lublin] 2017, s. 114.

${ }^{24}$ Ibidem, s. 115. 
Jest faktem, iż greccy i ormiańscy kupcy ze sobą konkurowali. W Komyszach występuje grecki kupiec Zabagos, któremu udało się uzyskać koncesję na założenie domu uzdrowiskowego i eksploatację gorących źródeł. Starali się o nią też Ormianie. Nie uzyskawszy jej, znienawidzili rywala. Ormianom przypisywano bogactwo. Staś podczas swego kilkumiesięcznego pobytu w kozackiej stanicy niekiedy droczył się z dziewczyną imieniem Odarka. Raz zarzucił jej, oczywiście w żartach, lenistwo:

Trzeba było wyjść za mąż za ormiańskiego kupca, to byś teraz na otomanie siedziała i sorbety popijała ${ }^{25}$.

W pierwszej powieści cyklu znajdujemy scenę z kupcem Czacharianem. Staś zachodzi do niego, by kupić kolczyki i broszkę dla Szury i umiejętnie się przy tym targuje.

Czacharian miał na sobie [...] aksamitną kurtkę i czarną jedwabną myckę na głowie. Między bujnym wąsem i przeciętą w klin bródką widniały pełne, niemal pąsowe usta. W swoim czasie Ormianina posądzano o malowanie warg, ale parokrotnie ponawiane próby $\mathrm{z}$ chustką umoczoną $\mathrm{w}$ spirytusie nie dały żadnego wyniku ${ }^{26}$.

Czacharian prowadzi sklep, będący równocześnie antykwariatem i lombardem, który prosperuje także po nastaniu władzy bolszewickiej. Kogoś takiego brakuje Stasiowi w stanicy. Zadurzywszy się tam w kolejnej pannie, chce jej kupić prezent, ale nie ma gdzie.

Żeby tak w Jejsku albo Dołżańsku, toby poszedł do pierwszego lepszego Ormianina i nie byłoby kłopotu ${ }^{27}$.

Ale czasy ormiańskich kupców dobiegają końca. Przekonują się o tym Staś i Katia, poszedłszy na jarmark, o wiele uboższy niż w czasach przedrewolucyjnych, bo już bez Ormian, a także Greków i Persów. Dodać tu też należy, że sam Aszwajanc to również człowiek bardzo bogaty. Nie wiadomo jednak, na czym zdołał się tak dorobić. Na pewno jego interesy nie zawsze były legalne.

Powieściowi Ormianie należą również do ludzi znakomicie poinformowanych. Wspomniana Odarka, która została kochanką Hassana, perskiego kupca, dowiedziała się od niego o planowanym napadzie na stanicę.

On z Armiaszkami kombinuje [...] - mówi - a ci zawsze pierwsi przewąchują ${ }^{28}$.

25 J. Łobodowski, W stanicy, [Lublin] 2017, s. 11.

${ }^{26}$ Id em, Komysze, [Lublin] 2017, s. 256.

${ }^{27}$ Id em, W stanicy, s. 254.

${ }^{28}$ Ibidem, s. 423. 
Oczywiście pod tym względem bezkonkurencyjny jest Grisza. Dzięki temu, że wszystko wie o wszystkich, wielokrotnie ratuje swego polskiego kunaka. Gdy Staś wydostał się z sierocińca, nie mógł pozostać w Jejsku, nawet w ukryciu, gdyż prędzej czy później zostałby ponownie ujęty. Ormianin pomógł mu uciec i ukryć się w Nachiczewaniu, ormiańskiej dzielnicy Rostowa nad Donem, którą Staś miał okazję dobrze poznać.

Po półgodzinnym marszu zagłębił się w gąszcz uliczek ludnej dzielnicy. Niewielkie, przeważnie murowane domy, mnóstwo sklepów, w większości pozamykanych, tu i ówdzie zabitych deskami na głucho. Chmary smagłych, czarnowłosych i czarnookich dzieciaków. Na ławeczkach pokurczone postacie starców i staruch, rozleniwionych sennie w cieple letniego wieczoru ${ }^{29}$.

Ormianie w Rostowie zdają się dość liczni. Choć to już czasy porewolucyjne, kupcy dzięki swej obrotności i solidarności jakoś sobie radzą. Widać ich handlujących na tamtejszych bazarach. W powieści jest scena napadu bezprizornych na handlarkę wędlinami. A może to początek dobrego dla nich okresu - właśnie zaczyna się NEP, czyli Nowa Polityka Ekonomiczna, częściowo dopuszczająca kapitalizm w pierwszym państwie socjalistycznym. Staś i Szura ukrywają się u Tiny, garbatej Ormianki, która czasami wróży z kart. Wywróżyła im, że

czarna chmura coraz niżej [...], kto przed czarną chmurą nie ujdzie na czas, tego ogarnie i pochłonie ${ }^{30}$,

co niestety się sprawdziło.

W Drodze powrotnej niemało jest o historii Ormian. Trzeba zatem znów przywołać Griszę Aszwajanca, bo to on jest tu największym jej znawcą. W rozmowie ze wspomnianym wyżej Awdotienką wykłada wręcz całe dzieje swego narodu:

Wy na nas: „Karapiety”, „Soleni” - a my się z was tylko w kułak śmiejemy. My Ormianie inny mamy pomyślunek i sposób [...]. Jakbyś zajrzał do książek, to byś się przekonał. Ormiańskie państwo istniało rozległe i bogate, zanim jeszcze Moskwa powstała i nawet o wiele dawniej. Myśmy już szaszłyk jedli, dobrym winem zapijali, jak wyście po drzewach łazili i brzozową korę ćkali. Dopiero potem zaczęły na nas różne nieszczęścia się walić. A to różne Arapyagariańskie, a to horda tatarska, Persowie, Turcy... Z tymi najgorzej. Inni, Tatarzy na przykład, przyszli, pograbili, ludzi natłukli, najładniejsze baby uprowadzili, ale potem szli w pioruny, tylko się za nimi kurzyło. Więc Tatarzy nie byli tacy źli, bo przychodzili i odchodzili. A w końcu całą ich potęgę diabli wzięli, bo się kupy nie trzymali, porozłazili się po świecie, niczym wszy po waszej RFSRS. Dlatego dziś

29 J. Łobodow ski, Droga powrotna, s. 315.

${ }^{30}$ Ibidem, s. 312. 
Tatarzy nic nie znaczą. Albo buty na ulicy czyszczą, albo dywany sprzedają. Na to na starość im przyszło. A Turcy pod bokiem się osiedlili, fortece nabudowali, swoich baszów i agów pousadzali. I przyszły na Ormian złe czasy. Jeszcze Kurdów na nas nasyłali, a to dzikie plemię, tyle umie, że ludzi morduje i grabi. Jeszcze później biały car zaczął swoje władztwo na Kaukazie. Chytrze sobie poczynał. Że niby chrześcijanin przed niewiernym bisurmanem broni i ich z niewoli wyzwala ${ }^{31}$.

Aszwajanc przypomniał przy okazji tego ,wykładu”, że Ormian w Rosji nazywało się nie tylko „Karapietami”, ale też „Solonymi”. Skąd się wzięło to drugie przezwisko, wyjaśnia Czubar, Kozak ze stanicy, w której przebywał Staś: bo ,jak ichni pop chrzci, to do wody garść soli wrzuca"32. Sam Staś natomiast „czytał kiedyś w jakiejś książce historycznej, że w Polsce od dawna zamieszkują Ormianie, głównie we Lwowie”33. Aszwajanc o tym także wie: „Porozrzucało nas po całym świecie" 34 .

Nie mogło zabraknąć w Drodze powrotnej choćby wzmianki na temat ludobójstwa Ormian w Turcji w 1915 roku. Akcja powieści rozgrywa się zaledwie kilka lat po tych wydarzeniach. Czyni do nich aluzję Aszwajanc w swym wykładzie. Ale pojawiają się one też w opowieści Czubara. Ów Czubar podczas pierwszej wojny światowej był na froncie tureckim, wśród gór za Erywaniem, w miejscowości Igdir. „Została tam garść Ormiaszek, którzy zdążyli się na czas pochować w górach"35 i dlatego nie zostali przez Turków wymordowani. Gdy stacjonowali tam Rosjanie, mogli czuć się w miarę bezpiecznie. Świadczyli im rozmaite usługi w zamian za jedzenie. Dziewczęta oddawały się żołnierzom za kawałek chleba.

Ormianie i sprawy ich dotyczące, tak często opisane na kartach trylogii Łobodowskiego, z pewnością zmuszają do zastanowienia. Skąd pisarz czerpał wiadomości, które posłużyły mu do kreacji ormiańskich bohaterów, do poruszenia różnych ormiańskich kwestii? Dlaczego w ogóle wprowadził ich do swoich powieści, poświęconych wszakże polskiemu losowi?

Jak już wyżej pisałem, w swoich powieściach zawarł Łobodowski bardzo dużo z tego, co sam znał z autopsji. Opisując zatem Kubań i Jejsk, zamieszkałe przez przedstawicieli rozmaitych ludów, nie mógł pominąć Ormian. Podobnie Stefan Żeromski, opowiadając w Przedwiośniu losy Cezarego Baryki, który żył w Baku, mniej więcej w tym samym czasie, co Staś Majewski w Jejsku, uwzględnił sprawy tamtejszych Ormian. Ale przecież Łobodowski mógł ich tylko wspomnieć. A tymczasem Ormianie są o wiele bardziej obecni w jego trylogii.

\footnotetext{
31 Ibidem, s. 125-127.

32 Ibidem, s. 350.

${ }^{33}$ Ibidem, s. 96.

34 Ibidem, s. 234.

35 J. Łobodowski, W stanicy, s. 350.
} 
Prawdopodobnie rodzina Łobodowskich podczas pobytu w Jejsku miała bliższe kontakty z miejscowymi Ormianami, pozostawała chyba z nimi w zażyłości. Pisarz w Żywocie czlowieka gwaltownego, wspominając śmierć ojca, pisze: „ormiański ksiądz pobłogosławił zwłoki”36. Natomiast w powieści $W$ stanicy zamieszcza wspomnienie o Bożym Narodzeniu, spędzonym w tym mieście przed dwoma laty, kiedy to

był $\mathrm{z}$ rodzicami na nabożeństwie $\mathrm{w}$ ormiańskiej kaplicy, bo ksiądz Dobrzański właśnie zachorował na tyfus plamisty, więc polskiej pasterki nie było [...]. Pamięta, jak ksiądz ormiański, wysoki, bardzo szczupły, o smagłej twarzy i płomiennych oczach podszedł do grupy Polaków i łamał się z nimi opłatkiem ${ }^{37}$.

Jeśli to zdarzenie - bardzo zresztą ekumeniczne - nie jest wyłącznie fikcją literacką, a zostało przeżyte przez rodzinę Łobodowskich, mogło przyszłego poetę uczynić na całe życie przyjacielem Ormian.

Nie bez znaczenia jest także to, że Łobodowski był erudytą. Doskonale orientował się w dziejach i kulturze krajów Europy Wschodniej. Zachował się jego list do Stefanii Kosowskiej, redaktorki naczelnej londyńskich „Wiadomości”, w którym krytykuje Wacława Zbyszewskiego, twierdzącego, iż narody imperium osmańskiego żyły ze sobą w przykładnej zgodzie ${ }^{38}$. Oprócz tego trzeba zwrócić uwagę na fakt, iż w drugiej połowie lat trzydziestych Łobodowski był związany $\mathrm{z}$ ruchem prometejskim ${ }^{39}$. Ruch ten, popierany przez polskie władze państwowe, miał na celu nawiązanie jak najlepszych więzi ze wszystkimi narodami uciemiężonymi przez Rosję sowiecką ${ }^{40}$. Służyła temu między innymi popularyzacja ich dorobku artystycznego. Łobodowskiemu szczególnie zależało na kontaktach z Ukraińcami, ale bliskie były mu też ludy Kaukazu, o czym świadczy fakt, że thumaczył poemat Szoty Rustawelego Rycerz w tygrysiej skórze, w czym pomagali mu wydatnie emigranci gruzińscy ${ }^{41}$. Ideałom ruchu prometejskiego pozostał wierny również wtedy, gdy sam stał się emigrantem, na co dowodem jest spora część jego twórczości. W omawianej trylogii jest więc sporo na temat Ormian, choć prometejczycy mieli z nimi niejaki problem z powodu ich prorosyjskości, obecnej także wśród wychodźstwa politycznego ${ }^{42}$.

36 Idem, Żywot człowieka gwałtownego, oprac. J. Trznade1, Warszawa 2014, s. 37.

${ }^{37}$ Idem, W stanicy, s. 307.

${ }^{38}$ Id em, Listy do redaktorów , Wiadomości”, oprac. P. Libera, konsult. B. Dorosz, Toruń 2015, s. 306.

39 Idem, Żywot, s. 107, 189-190, 274-275.

${ }^{40}$ L. Wyszczelski, Polska mocarstwowa. Wizje i koncepcje obozów politycznych II Rzeczypospolitej, Warszawa 2015, s. 198, 201, 214, 219.

41 J. Łobodowski, Żywot, s. 190.

${ }^{42}$ II Rzeczpospolita wobec ruchu prometejskiego, 4, red. P. Libera, Warszawa 2013, S. 54-55. 
Bezsprzecznie Ormianie w omawianym cyklu powieściowym nie stanowią „orientalnego ozdobnika”. Łobodowski, pisząc o nich, realizował poważniejszy zamysł. Zdaje się sugerować, że przyjaźń między Stasiem Majewskim a Griszą Aszwajancem to nie tylko nieprawdopodobne przygody, to przede wszystkim skuteczny sojusz słabych wobec zagrażających im potęg. Że taki sojusz wcale nie musi być czymś odosobnionym, lecz łączyć może wręcz całe narody. Niestety ta sugestia przez kilkadziesiąt lat nie mogła dotrzeć do zbyt wielu ludzi czytających po polsku. Jednakże docierając teraz, pozostaje nadal w pełni aktualna.

\title{
Bibliografia
}

\section{Źródła drukowane}

Łobodowski J., Żywot czlowieka gwałtownego, oprac. J. Trznadel, Warszawa 2014

Łobodowski J., Listy do redaktorów ,Wiadomości”, oprac. P. Libera, konsult. B. Dorosz, Toruń 2015

Łobodowski J., Komysze, [Lublin] 2017, Kraków 2020

Łobodowski J., W stanicy, [Lublin] 2017

Łobodowski J., Droga powrotna, [Lublin] 2017

\section{Opracowania}

Danilewicz-Zielińska M., Szkice o literaturze emigracyjnej, Wrocław 1999

[Druga] II Rzeczypospolita wobec ruchu prometejskiego, red. P. Libera, Warszawa 2013 Jakubowska-Ożóg A., Poezja emigracyjna Józefa Łobodowskiego, Rzeszów 2001

Kaliściak T., Pobratymstwo w świetle źródet historyczno-etnograficznych z przełomu XVIII i XIX wieku, „Konteksty”, 4, 2020, s. 209-217

Kościów Z., Motyw ormiański w literaturze polskiej, „Opole”, 8, 1987

Libera P., Na marginesie „Dziejów Józefa Zakrzewskiego” (uwagi historyka), w: J. Łobodowski, Dzieje Józefa Zakrzewskiego, Część czwarta, Rzeka graniczna, b.m.w. 2018, s. $243-251$

[Sielickij A.] Селицкий А., Поляки на Кубани. исторические очерки, Краснодар 2008 Siryk L., Naznaczony Ukraina. O twórczości Józefa Lobodowskiego, Lublin 2002

Szypowska I., Łobodowski. Od „, atamana Łobody” do „,seniora Lobo”, Warszawa 2001 Ursel M., Romantyzm, Wrocław 2000

Wyszczelski L., Polska mocarstwowa. Wizje i koncepcje obozów politycznych II Rzeczypospolitej, Warszawa 2015

\section{Grzegorz Pelczyński, Grisha Ashvayants and other Armenians in the Ukrainian trilogy of Józef Lobodowski}

\begin{abstract}
The article analyses the image of Armenians and their fate in the novel cycle of the Polish emigratory writer Józef Łobodowski (1909-1988). This cycle, called the Ukrainian trilogy (Komysze, 1955; W stanicy, 1958; Droga powrotna, 1960), is based on experiences of the author, who spent his youth in Kuban during World War One and the period shortly after the Bolshevik revolution. In this trilogy,
\end{abstract}


Armenians do not constitute only the oriental decoration. Writing about these people, Łobodowski realised more serious intention. He seems to indicate that friendship between the novel hero Staś Majewski and the Armenian boy Grisha Ashvayants means not only incredible adventures but primarily the effective alliance of the weak against threatening powers. This alliance is not only individual but also uniting even the whole nations.

Keywords: Józef Łobodowski, Kuban, Armenians, Polish literature

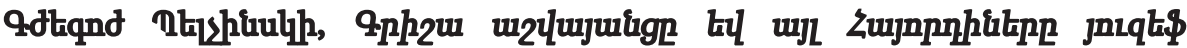

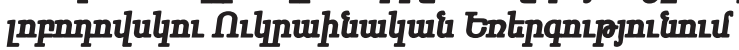

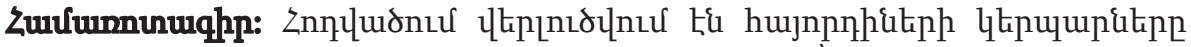

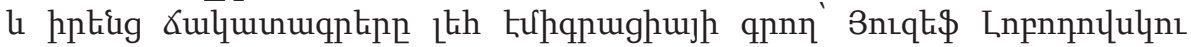

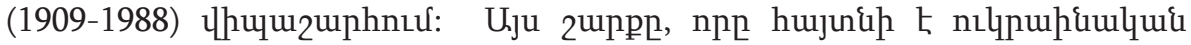

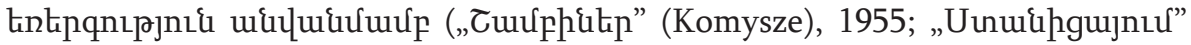

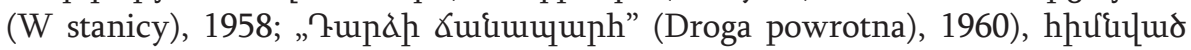

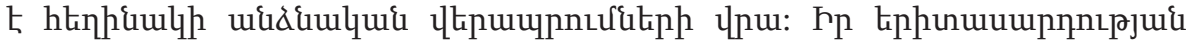

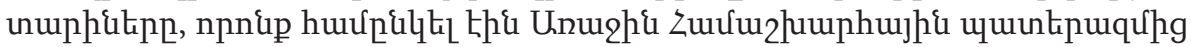

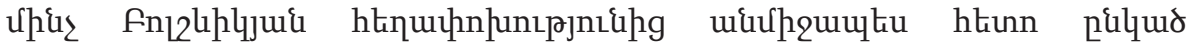

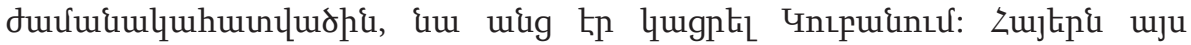

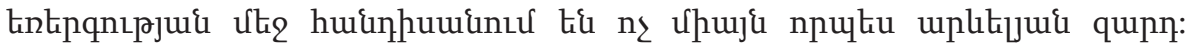

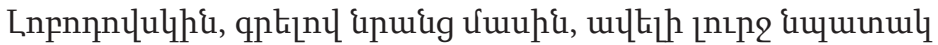

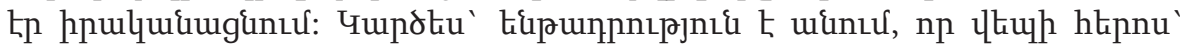
Unuw2 Uuliulyns

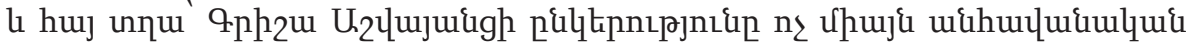

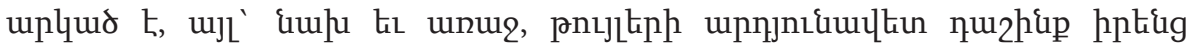

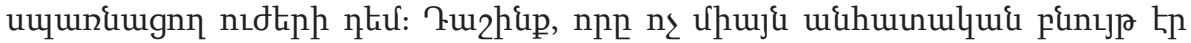

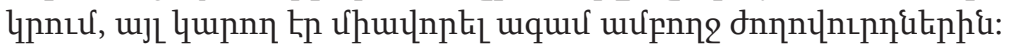

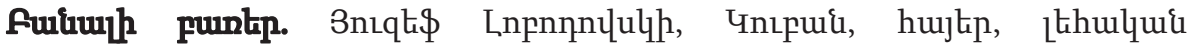
qpulquinıpjnıq: 


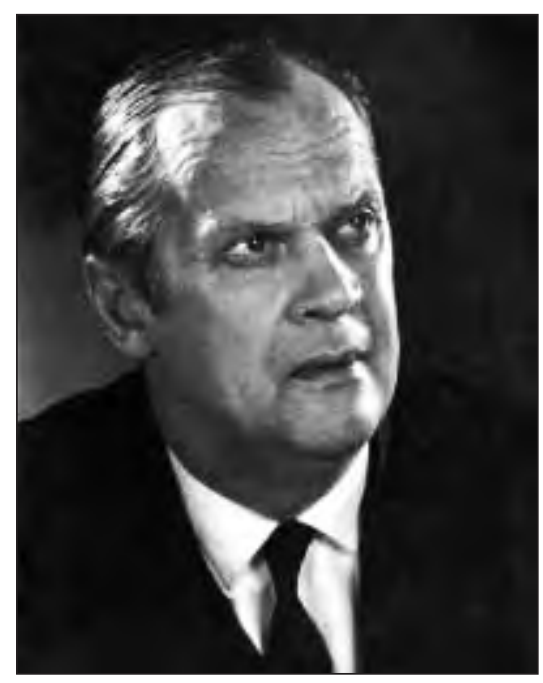

1. Józef Łobodowski

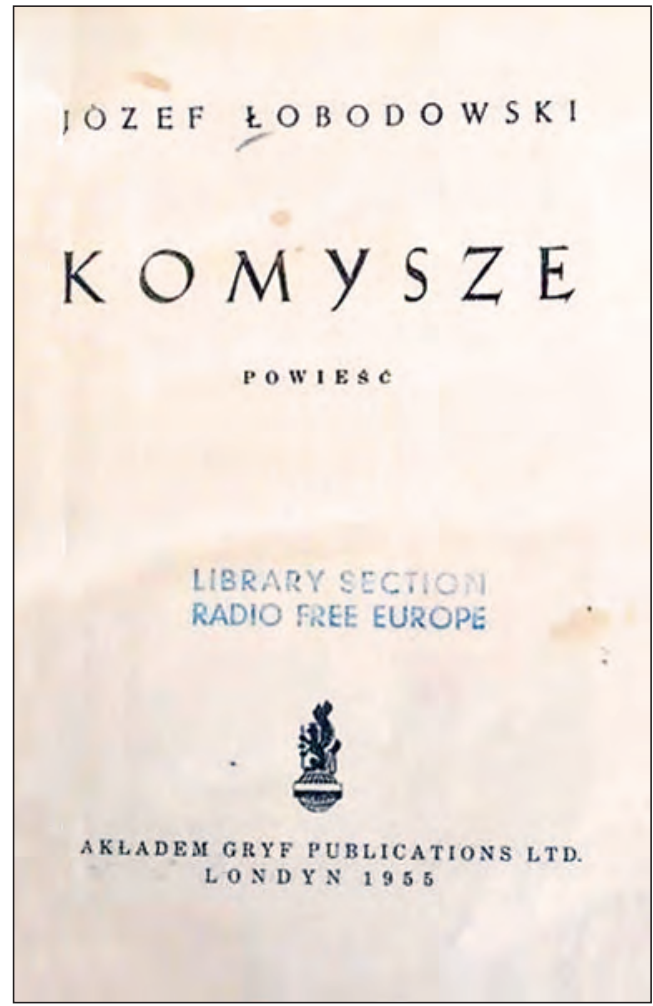

2. Pierwsze wydanie Komyszy Józefa Łobodowskiego, Londyn 1955 